\author{
KATARZYNA ŁUCARZ \\ ORCID: 0000-0003-3130-2389 \\ Uniwersytet Wrocławski \\ Zakład Prawa o Wykroczeniach, Karnego Skarbowego i Karnego Gospodarczego
}

\title{
KILKA UWAG NA TEMAT AKTUALNEGO MODELU ŚRODKÓW ODDZIAŁYWANIA WYCHOWAWCZEGO
}

\begin{abstract}
Abstrakt: Autorka w niniejszym opracowaniu omawia instytucję, która umożliwia załatwienie sprawy o wykroczenie w innym trybie i z zastosowaniem innych środków niż przewidziane w przepisach karnych. Podkreślając niewątpliwe walory takiego rozwiązania, wskazuje jednocześnie, że konstrukcja środków oddziaływania wychowawczego nie jest pozbawiona wad i niedociągnięć. Uwagę koncentruje zwłaszcza na tych aspektach jej funkcjonowania, które wymagają pilnej interwencji ze strony ustawodawcy. Autorka konkluduje, że pozostawienie omawianego unormowania bez żadnych zmian naraża je na sprzeczność z jedną z fundamentalnych zasad prawa karnego, a mianowicie zasadą nulla poena sine lege.
\end{abstract}

Słowa kluczowe: wykroczenie, środki oddziaływania wychowawczego, alternatywa ukarania

Spojrzenie na konstrukcję środków oddziaływania wychowawczego z punktu widzenia prawa karnego prowadzi niekiedy do formułowania postulatu ostrożnego i rozważnego operowania nimi. Wyjątkowa w tej mierze powściągliwość niektórych autorów bierze się najogólniej z przekonania, że ustawodawca nie jest w stanie należycie oraz ściśle zdefiniować istoty tych środków, co pociąga niemożność prawidłowego wyznaczenia konsekwencji za czyn będący wykroczeniem. Trzeba bowiem pamiętać, że instytucja środków oddziaływania wychowawczego nie ma jednorodnego charakteru prawnego. O ile w płaszczyźnie procesowej odzwierciedla ona uznaną i powszechnie akceptowaną w prawie wykroczeń zasadę celowości ścigania, o tyle rozpatrywana na gruncie materialnoprawnym oznacza $\mathrm{w}$ istocie zinstytucjonalizowany sposób reakcji na stwierdzone popełnienie wykroczenia ${ }^{1}$. W celu uniknięcia możliwych nieporozumień dodajmy, że wskazana alternatywa interesuje nas tu wyłącznie w znaczeniu prawnomaterialnym, pozwalającym traktować ją właśnie w kategorii samodzielnego rodzaju odpowiedzi na wykroczenie. A skoro tak, regulacja dotycząca środków oddziaływania wychowawczego po-

1 J. Skupiński, Kierunki doskonalenia polskiego prawa wykroczeń, SP 1981, nr 4, s. 6. 
winna, respektując gwarancyjną funkcję prawa karnego, czynić zadość wszystkim standardom przewidzianym dla środka penalnego ${ }^{2}$. Tymczasem bliższy wgląd w jej treść pozwala stwierdzić, że sporne jest tu w zasadzie niemal wszystko. Rozliczne wątpliwości oraz niejasności powstają już co do samej nazwy tych środków, pogłębiają się zaś przy próbie rekonstrukcji kryteriów ich zastosowania. Następnie dochodzą do głosu w zakresie wykładni adresata i nie omijają przedmiotowego zasięgu obowiązywania omawianego unormowania. Nieudolność ustawodawcy daje wreszcie znać o sobie tam, gdzie dochodzi do kumulacji dolegliwości płynącej z zastosowania niejako podwójnej represji.

Tak czy inaczej dalekie od precyzji ujęcie środków oddziaływania wychowawczego sprawia, że obecna ich formuła wzbudza więcej kontrowersji, znacznie mniej natomiast pewności odnośnie do tego, czy może ona stać się autentyczną alternatywą dla penalnych form reakcji na wykroczenie. A przecież taki zamysł towarzyszył wprowadzeniu konstrukcji środków oddziaływania wychowawczego do polskiego systemu prawa wykroczeń. Przypomnijmy, że jednym z podstawowych założeń reformy prawa wykroczeń z 1966 roku³ było odejście od czysto represyjnego kierunku orzecznictwa karno-administracyjnego. Przywróceniu zaburzonych uprzednio proporcji między elementem represyjnym a wychowawczym służyć miało przede wszystkim uelastycznienie oraz zracjonalizowanie reakcji stosowanej dotychczas wobec sprawców czynów drobniejszej natury. W efekcie tej reorientacji tradycyjny katalog instrumentów wzbogacono między innymi o rozwiązanie zakładające odmowę wszczęcia postępowania przez przewodniczącego kolegium, połączoną z przekazaniem sprawy

kierownikowi zakładu pracy, w którym sprawca był zatrudniony, z wnioskiem o zastosowanie środków przewidzianych w regulaminie pracy lub postępowaniu dyscyplinarnym albo innych środków oddziaływania wychowawczego, jeżeli z charakteru popełnionego czynu wynikało, że stanowi on jednocześnie naruszenie obowiązków pracowniczych (art. $28 \mathrm{pkt} 6)^{4}$.

Z tych samych względów przewodniczący mógł w ogóle zaniechać wszczęcia postępowania, jeżeli przed skierowaniem sprawy do kolegium zastosowano już wobec sprawcy w zakładzie pracy przedmiotowe środki. Przywołane rozwiązanie nie było jednak czymś zupełnie nieznanym praktyce orzeczniczej. Tego rodzaju „przekładnia”, umożliwiająca załatwienie sprawy o wykroczenie w innym trybie i z zastosowaniem innych środków niż przewidziane w przepisach karnych,

2 J. Szumski, Środki alternatywne wobec kary za wykroczenia (w związku z projektem kodeksu wykroczeń), PiP 1992, nr 12, s. 79.

3 Ustawa z dnia 17 czerwca 1966 roku o przekazaniu niektórych drobnych przestępstw jako wykroczeń do orzecznictwa karno-administracyjnego (Dz.U. z 1966 r. Nr 23, poz. 149).

${ }^{4} \mathrm{Z}$ ogółu unormowań ustawy wynikało, że środki oddziaływania wychowawczego mające charakter wychowawczy lub niekiedy nawet czysto represyjny nie mogły być identyfikowane z karą w rozumieniu prawa karnego. I to pomimo że z reguły były one wyraźnie przewidziane w normach prawa, a ich wykonanie zabezpieczano sankcją przymusu państwowego (tak J. Skupiński, Model polskiego prawa o wykroczeniach, Warszawa 1974, s. 154-155). 
funkcjonowała także nieco wcześniej ${ }^{5}$, co wiązało się z występującą w dziedzinie prawa wykroczeń zasadą celowości ścigania czynów drobniejszych ${ }^{6}$. W pewnym sensie unormowanie to było kolejnym przykładem dostosowania norm prawnych do wymogów stawianych przez ówczesne życie ${ }^{7}$. Jedyna różnica polegała na tym, że od momentu prawnego uregulowania tej kwestii rezygnacja ze ścigania musiała iść $\mathrm{w}$ parze $\mathrm{z}$ reakcją $\mathrm{w}$ postaci środków oddziaływania wychowawczego ${ }^{8}$. Takie postawienie sprawy domagało się jednakże jasnego stanowiska co do kształtu prawnego tego środka oddziaływania ${ }^{9}$. Niestety już wtedy ustawa zadowoliła się dość skrótowym jego ujęciem. Kierownik zakładu miał bowiem możliwość zastosowania wobec sprawcy nie tylko środków przewidzianych w regulaminie pracy czy postępowaniu dyscyplinarnym, lecz także bliżej nieokreślonych środków oddziaływania wychowawczego. Nieostrość i rozległość tego ostatniego pojęcia oraz zbytnia dowolność w wyborze sposobu reakcji na popełnienie wykroczenia mogły niewątpliwie stwarzać pokusę nadużyć. I zamiast sprzyjać łagodzeniu odpowiedzialności za wykroczenie nieopacznie prowadzić do jej zaostrzenia. Poza tym brak wyczerpującego wyliczenia środków oddziaływania wychowawczego nie spełniał wymogu określoności prawnokarnej reakcji na czyn zabroniony, pozostawał zatem w całkowitej sprzeczności z zasadą nulla poena sine lege.

$\mathrm{Z}$ identycznych powodów dyskusyjna okazała się też sama podstawa przekazania sprawy, która sprowadzała się wyłącznie do przeświadczenia przewodniczącego kolegium, że decyzja ta będzie „wystarczająca dla wdrożenia sprawcy do poszanowania prawa i zasad współżycia społecznego"10. Podbijał ją dodatkowo fakt, że decyzję o przekazaniu sprawy podejmowano jednoosobowo na podstawie materiałów oskarżenia, które z reguły nie zawierały szerszych informacji o osobie sprawcy oraz okolicznościach popełnienia czynu. Wynikająca z tego przypadkowość w oczywisty sposób kolidowała z zasadą indywidualizacji orzekania. Co ważniejsze jednak, taka decyzja naruszała również prawo do obrony obwinionego, chociaż w praktyce oznaczała nieformalne uznanie jego winy. Na podstawie dowodów zgromadzonych przez oskarżenie decyzja zapadała pod nieobecność

5 A. Gubiński, Prawo wykroczeń, Warszawa 1989, s. 227.

${ }^{6}$ A. Gubiński, Prawo karno-administracyjne, Warszawa 1968, s. 182; idem, Środki oddziabywania wychowawczego na tle zasady celowości w prawie wykroczeń, PiP 1972, nr 10, s. $31 \mathrm{n}$.

7 J. Skupiński, Obowiązek sktadania przez organy państwowe wniosków o ukaranie przez kolegia karno-administracyjne, [w:] Funkcjonowanie administracji w świetle orzecznictwa, t. 3, Warszawa 1971, s. 236-237.

8 J. Szumski, Środki penalne w polskim prawie wykroczeń na tle doświadczeń praktyki, Lublin 1995, s. 88.

9 J. Skupiński, Kierunki doskonalenia..., s. 6.

10 Interpretując ten przepis, w literaturze wskazywano na równie ocenne kryteria. Przyjmowano mianowicie, że przekazanie „może dotyczyć wyłącznie wypadków, które charakteryzują się znikomym ładunkiem niebezpieczeństwa społecznego (ze względu na sam czyn i jego okoliczności bądź na osobę sprawcy w świetle tego, co o nim wiadomo z akt i z ewentualnych informacji uzyskanych z zakładu pracy)" - A. Gubiński, M. Siewierski, Ustawa o przekazaniu niektórych drobnych przestępstw jako wykroczeń do orzecznictwa karno-administracyjnego. Komentarz, Warszawa 1967, s. 158. 
obwinionego, który nie miał nawet możliwości złożenia wyjaśnień. Do tego dochodziło jeszcze pominięcie zastrzeżenia, aby ze zgromadzonych dowodów nie wynikało, że obwiniony kwestionuje popełnienie zarzucanego mu czynu, a jego wina oraz okoliczności popełnienia wykroczenia budzą jakiekolwiek wątpliwości ${ }^{11}$. Nadużycia dotyczyły także interesów pokrzywdzonego, który składając wniosek o ukaranie, miał przecież prawo spodziewać się rozpoznania sprawy przez kolegium, a nie zakład pracy.

Wskazane tu przykładowo niedostatki omawianego uregulowania nie deprecjonowały bynajmniej jego wartości ${ }^{12}$. W literaturze przedmiotu właściwie nie kwestionowano potrzeby istnienia tego typu pozakarnych form oddziaływania na sprawców wykroczeń. Mówiło się nawet o zasadzie preferencji tego rodzaju środków ${ }^{13}$. Wynikała ona między innymi ze wspomnianej już zasady celowości ścigania drobniejszych czynów karalnych. Rezygnacja z obowiązku ścigania na rzecz nakazu prawnego reagowania na czyn zabroniony w drodze środków niepenalnych łączyła się też ściśle z przedmiotem normowania prawa wykroczeń, które zasadniczo obejmowało zachowania charakteryzujące się in genere niższą społeczną szkodliwością. Zakładano przy tym, że w wypadku niektórych z nich potencjał karygodności w konkretnej sprawie może ulec redukcji do tego stopnia, że w ogóle odpadną jakiekolwiek powody do ukarania (stanie się ono albo całkowicie bezcelowe, albo w najlepszym wypadku nadmierne). W rezultacie takiego postawienia sprawy nie powinno dziwić, że idea alternatywnej płaszczyzny oddziaływania została niemal w całości inkorporowana przez kodeks wykroczeń z 1971 roku $^{14}$. A ponieważ wprowadzone zmiany polegały głównie na jej uwspółcześnieniu, nie doszło tu przeto do poważniejszych przekształceń modelowych. Tak naprawdę w pierwszym okresie obowiązywania kodyfikacji z 1971 roku mieliśmy do czynienia z rozwiązaniem nawiązującym wyraźnie do wypracowanego oraz mocno już utrwalonego w tym względzie dorobku legislacyjnego. Zaobserwować można było jedynie rozszerzenie możliwości korzystania z tego sposobu reagowania. Zgodnie z art. 41 k.w. ${ }^{15}$ przekazanie sprawy nie ograniczało się jak

11 J. Szumski, Środki alternatywne..., s. 80-81.

$12 \mathrm{~W}$ związku z tym zgłoszono nawet postulat de lege ferenda, aby decyzję o przekazaniu sprawy podejmował skład orzekający po przeprowadzeniu rozprawy, a przekazanie łączyło się z instytucją odstąpienia od ukarania zamiast odmowy wszczęcia postępowania (J. Skupiński, Przekazanie niektórych drobnych przestępstw do orzecznictwa karno-administracyjnego, PiP 1967, nr 1, s. 114). Podkreślano jednak, że z kryminalnopolitycznego punktu widzenia takie rozwiązanie nie służyłoby ograniczeniu liczby spraw wpływających do kolegium.

13 Por. W. Radecki, [w:] M. Bojarski, W. Radecki, Kodeks wykroczeń. Komentarz, Warszawa 2016, s. 408; T. Grzegorczyk, [w:] Kodeks wykroczeń, red. T. Grzegorczyk, Warszawa 2013, s. 180; R. Krajewski, Środki oddziaływania wychowawczego w prawie wykroczeń, Pal. 2013, nr 7-8, s. 13-14.

14 Dz.U. z 1971 r. Nr 12, poz. 114.

15 Zgodnie z pierwotnym brzmieniem art. 41k.w.: „uznając, że jest to wystarczające do wdrożenia sprawcy wykroczenia do poszanowania prawa i zasad współżycia społecznego, można nawet nie wszczynając postępowania, przekazać sprawę kierownikowi zakładu pracy, w którym sprawca 
dotąd tylko do kierownika zakładu pracy, lecz obejmowało także sąd społeczny oraz organizację społeczną, poza tym przekazania takiego mógł dokonać poza przewodniczącym kolegium również sam skład orzekający na rozprawie, co miało sprzyjać zwiększeniu indywidualizacji oddziaływania ${ }^{16}$. Nieznaczne tylko rozwinięcie odziedziczonej po ustawie z 1966 roku regulacji środków oddziaływania wychowawczego doprowadziło jednak do tego, że większość zastrzeżeń formułowanych wobec pierwowzoru tej alternatywy zachowała swoją aktualność. Tak jak w wypadku koncepcji wyjściowej uważano, że instytucja ta jest swoistą mistyfikacją dla podtrzymywania złudzeń o wychowawczym wpływie środków stosowanych w jej ramach. W rzeczywistości bowiem wszystkie one miały stygmatyzujące właściwości ${ }^{17}$. A część swoją dolegliwością przewyższała nawet środki uznane formalnie za penalne. O tym, że oczekiwanie tego rodzaju miało istotnie charakter „życzeniowy”, przekonywało, dodatkowo niezwiązanie podmiotu, któremu sprawę przekazywano, treścią wniosku. Nie ciążył na nim również obowiązek informowania kolegium czy przewodniczącego o podjętej przez siebie decyzji. Na dobrą sprawę organ występujący z wnioskiem nie miał żadnego wpływu na wybór oraz samo zastosowanie przedmiotowego środka, co oczywiście potęgowało tylko ryzyko dowolności i niejednolitości w jego aplikowaniu. Równie ważne, o ile nie najważniejsze, było jednak to, że zamieszczone w kodeksie wykroczeń unormowanie dalej naruszało fundamentalne zasady prawa karnego oraz nie zapewniało dostatecznych gwarancji procesowych uczestnikom postępowania. Sprawy przekazywane były różnym podmiotom działającym na podstawie odmiennych procedur ${ }^{18}$.

Niewiele lepiej przedstawiało się faktyczne wykorzystanie przez kolegia instytucji przekazania sprawy do zakładu pracy czy organizacji społecznej w celu zastosowania środków oddziaływania wychowawczego. Okazało się, że pomysł ten, jakkolwiek słuszny w intencji, nie powiódł się do końca także w praktyce orzeczniczej. Kolegia tkwiły nadal w błędnym przekonaniu o skuteczności tradycyjnych instrumentów prawnokarnych w zwalczaniu drobnych naruszeń prawa. Niewykluczone, że za sprawą wad i niedostatków ustawowego ujęcia przedmiotowej konstrukcji. Z udostępnionych danych statystycznych wynika, że omawiana

jest zatrudniony, jeżeli z charakteru popełnionego czynu wynika, że stanowi on naruszenie obowiązku pracowniczego, albo sądowi społecznemu lub organizacji społecznej, do której sprawca należy, $\mathrm{z}$ wnioskiem o zastosowanie środków przewidzianych w regulaminie pracy, w postępowaniu dyscyplinarnym lub innych środków oddziaływania wychowawczego".

16 Tak K. Świtała, Nowe prawo o wykroczeniach, ZKA 1969, nr 6, s. 3.

17 J. Szumski, Środki penalne..., s. 118-119, 131.

18 Ibidem, s. 197-200. Autor zaznacza jednocześnie, że przyczyny takiego stanu rzeczy nigdy nie zostały wyjaśnione. Nie wiadomo zatem, czy decydujące znacznie miała w tym względzie selekcja we wcześniejszych stadiach postępowania, sprawiająca, że do kolegiów docierały relatywnie poważniejsze sprawy, czy też po prostu stosujący prawo nie mieli większego przekonania o celowości przekazywania spraw innym podmiotom. 
alternatywa ukarania stosowana była w praktyce wręcz incydentalnie ${ }^{19}$. Udział spraw przekazanych na podstawie art. 41 k.w., liczony od ogółu wpływających wniosków o ukaranie, oscylował w latach siedemdziesiątych w granicach niespełna $2 \%$, spadając $w$ następnej dekadzie do zaledwie $0,5-0,7 \%{ }^{20}$. Z punktu widzenia ekonomii procesowej stanowił zatem bezużyteczny „ozdobnik”. Ze względu na utrzymujący się kryzys sądownictwa społecznego sprawy te trafiały niemal wyłącznie do zakładów pracy, stosowane zaś przez nie reakcje nie należały do najłagodniejszych. Polegały najczęściej na różnych formach represji ekonomicznej, na przykład pozbawieniu (zmniejszeniu) premii, nagrody czy wreszcie tak zwanej trzynastej pensji, nieco rzadziej przybierały postać upomnienia lub ostrzeżenia. Zdarzały się też przypadki dyscyplinarnego zwolnienia z pracy ${ }^{21}$. Zaprezentowane dane potwierdziły więc wcześniejsze przypuszczenie, że konsekwencje ponoszone przez sprawców w wyniku przekazania sprawy były dla nich nierzadko bardziej dolegliwe aniżeli ewentualne ukaranie przez kolegium. I że wychowawcze oddziaływanie niestety mylnie utożsamiano ze zwiększeniem dolegliwości dosięgającej sprawcę przez napiętnowanie go w środowisku pracy22.

Mimo tych negatywnych doświadczeń nowelizacja kodeksu wykroczeń z 1998 roku $^{23}$ zachowała możliwość stosowania wobec sprawców wykroczeń środków oddziaływania wychowawczego, chociaż poddała je pewnym przeobrażeniom. W utrzymanym po nowelizacji rozdziale zatytułowanym „Zastosowanie środków oddziaływania wychowawczego" skreślono bowiem art. 40 k.w. i zmodyfikowano treść art. 41 k.w., który zgodnie z aktualnym brzemieniem stanowi, że „w stosunku do sprawcy czynu można poprzestać na zastosowaniu pouczenia, zwróceniu uwagi, ostrzeżenia lub zastosowaniu innych środków oddziaływania wychowawczego". Łatwo zauważyć, że art. 41 k.w. (odpowiadający faktycznie dawnemu, aczkolwiek zmienionemu art. $40 \mathrm{k} . w .{ }^{24}$ ) ponownie został ujęty zbyt ogólnikowo. Wychodząc naprzeciw postulatom nauki prawa karnego, zrezygnowano co praw-

19 J. Jakubowska-Hara, Wymiar kary za wykroczenia (rozwój ustawodawstwa do kodyfikacji z 1971 r.), SP 1989, nr 4, s. 97-99.

20 J. Szumski, Środki alternatywne..., s. 79.

21 T. Sikorska, Przekazano zakładowi pracy... Pierwsze doświadczenia i wnioski - na tle badań przeprowadzonych $w$ Warszawie, ZW 1972, z. 2, s. 25 n.; M. Błotnicka-Solak, Tropami spraw przekazanych $i$ wystapień sygnalizacyjnych. Z badań nad skutecznościa stosowania art. 41 k.w. i art. 5 k.p.w. w praktyce kolegiów woj. tarnowskiego), ZW 1978, z. 1, s. 51 n.

22 J. Szumski, Środki penalne..., s. 131.

${ }^{23}$ Ustawa z dnia 28 sierpnia 1998 roku o zmianie ustawy - Kodeks wykroczeń, ustawy Kodeks postępowania w sprawach o wykroczenia, ustawy o ustroju kolegiów do spraw wykroczeń, ustawy - Kodeks pracy i niektórych innych ustaw (Dz.U. Nr 113, poz. 717).

24 Art. 40 k.w. upoważniał organy uprawnione do ścigania wykroczeń do niekierowania sprawy do kolegium do spraw wykroczeń i poprzestaniu tylko na zastosowaniu środków przewidzianych w regulaminie pracy, w postępowaniu dyscyplinarnym, w postępowaniu przed sądami społecznymi lub innych środków oddziaływania wychowawczego, jeśli były one „wystarczające do wdrożenia sprawcy do poszanowania prawa i przestrzegania zasad współżycia społecznego" (§ 1), zastrzegając jednocześnie, że jeżeli przemawia za tym uzasadniony interes społeczny, prokurator może, mimo 
da z możliwości przekazania sprawy o wykroczenie pracodawcom i organizacjom społecznym, które jak wiadomo od samego początku obowiązywania wzbudzało wiele kontrowersji, nie zdołano jednak ostatecznie oczyścić formuły środków oddziaływania wychowawczego z wszystkich dotychczasowych niejasności. Można chyba nawet zaryzykować, że nadmierne uproszczenie regulacji art. 41 k.w. zaciemniło jeszcze bardziej obraz tej i tak już dość skomplikowanej materii. Przepis ten został zredagowany $\mathrm{w}$ taki sposób, że powiedziano w nim wiele, ale dość niejasno ${ }^{25}$. W rezultacie mamy tu do czynienia z konstrukcją, która wciąż nie może uporać się z większością kłopotów, na jakie natrafiała nauka prawa karnego tudzież praktyka w poprzednim stanie prawnym. Uświadomienie sobie tego faktu prowokuje z kolei do sformułowania kilku szczegółowych uwag na temat wybranych aspektów jej funkcjonowania. Zwłaszcza tych, które z powodu zaniedbań ze strony ustawodawcy wyraźnie dziś nie domagają.

Oceniając obecny kształt normatywny instytucji środków oddziaływania wychowawczego, nie sposób nie odnieść się chociażby do kwestii jej nazewnictwa. Trudno bowiem bez zastrzeżeń akceptować termin „środki oddziaływania wychowawczego". Sama egzemplifikacja przez kodeks wykroczeń tego rodzaju przedsięwzięć wydaje się do tego niewystarczająca, tym bardziej że w literaturze przedmiotu przyjmuje się, że środkami tymi są „wszelkiego rodzaju poczynania, których głównym lub ubocznym celem jest oddziaływanie wychowawcze, jeżeli obiektywnie zdolne są one (w szerszym czy węższym zakresie) realizować to zadanie"26. Przy takim wszak podejściu problematyczne staje się nie tylko skonkretyzowanie treści tego pojęcia, ale przede wszystkim zweryfikowanie na drodze empirycznej wychowawczych walorów objętego nim instrumentarium. Jak dowiodła swego czasu praktyka, przypisywanie przynajmniej części z nich funkcji wychowawczej okazało się nie całkiem wiarygodne. Mając zatem na uwadze te właśnie doświadczenia, a także niemożność wytyczenia w sposób pewny granic omawianego terminu, za w pełni usprawiedliwione należy uznać porzucenie aktualnego nazewnictwa na rzecz bardziej adekwatnych sformułowań, takich przykładowo jak ,środki oddziaływania pozakarnego”, „pozakarne środki reakcji” czy po prostu ,inne środki"27. Idzie tu w końcu o formę reakcji na wykroczenie, w której

wcześniejszego zastosowania środków oddziaływania wychowawczego, skierować sprawę do organu orzekającego $(\S 2)$.

25 T. Bojarski, Polskie prawo wykroczeń. Zarys wykładu, Warszawa 2014, s. 118.

26 A. Gubiński, Prawo wykroczeń, Warszawa 1980, s. 223. Autor ten wskazuje równocześnie, że pojęcie środka oddziaływania wychowawczego jest znacznie szersze od pojęcia środka wychowawczego.

27 Dla przykładu projekt kodeksu wykroczeń z 2002 roku odstępował od kwestionowanej nazwy, określając tę postać reakcji jako „inne środki” (J. Jakubowska-Hara, Kilka uwag w kwestii alternatywnych form reakcji na wykroczenia (w kontekście reformy prawa wykroczeń), [w:] Na styku prawa karnego i prawa o wykroczeniach. Zagadnienia materialnoprawne oraz procesowe. Ksiega jubileuszowa dedykowana Profesorowi Markowi Bojarskiemu, red. J. Sawicki, K. Łucarz, Wrocław 2016, s. 181). 
wypadku również ten aspekt nie powinien budzić żadnych wątpliwości czy też przykrych skojarzeń.

Kolejnym przykładem niedostosowania omawianej regulacji do aktualnych wymogów w zakresie stanowienia prawa jest katalog środków oddziaływania wychowawczego możliwych do zastosowania na jej podstawie. Wychodzi bowiem na to, że przepis art. $41 \mathrm{k}$.w. nie wprowadza żadnych ograniczeń przedmiotowych. Wręcz odwrotnie, używając sformułowania „inne”, daje tak naprawdę przyzwolenie na stosowanie, poza trzema w nim wymienionymi, także innych, bliżej nieokreślonych środków. Jednocześnie przekreśla precyzyjne zdekodowanie reakcji pozakarnej, skoro przy takim otwarciu nie wskazuje, jakiego rodzaju reakcję pozakarną ma jeszcze na myśli. O ile zatem wcześniej (do września 1998 roku) krąg podmiotów mogących stosować środki oddziaływania wychowawczego był w jakimś sensie określony, wobec czego ustanowione były też podstawowe środki będące w gestii tych podmiotów, głównie te, które występowały w regulaminie pracy i postępowaniu dyscyplinarnym, o tyle obecnie identyfikacja ich katalogu jest już poważnie utrudniona ${ }^{28}$. Co nie znaczy, że zupełnie niemożliwa. Na gruncie normatywnym podpowiedzi bowiem poszukuje się najczęściej w treści art. 61 $\S 1$ pkt 2 k.p.w., w myśl którego sąd może odmówić wszczęcia postępowania, a wszczęte umorzyć, jeśli zastosowano wobec sprawcy środek oddziaływania wychowawczego w postaci pouczenia, zwrócenia uwagi lub ostrzeżenia albo środek przewidziany w przepisach o odpowiedzialności dyscyplinarnej lub porządkowej. Natomiast w literaturze jako ,inne środki” przywołuje się z reguły te, które można było stosować w świetle poprzednio obowiązującej regulacji. Przykładowo wspomina się między innymi o środkach przewidzianych w przepisach porządkowych oraz dyscyplinarnych ${ }^{29}$, zawiadomieniu zakładu pracy lub organizacji społecznej, której członkiem jest sprawca, bądź poinformowaniu szkoły lub uczelni sprawcy o wykroczeniu ${ }^{30}$. Recepcja tego rodzaju rozwiązań wymaga jednak pewnej rozwagi. Należy bowiem przypomnieć, że stosowanie niektórych spośród nich już wtedy wywoływało wyraźny sprzeciw ze względu na stygmatyzujący charakter. Niewspółmierność negatywnych konsekwencji wypaczała dodatkowo ich sens oraz istotę. Środki te zamiast prowadzić do zmniejszenia ustawowej intensywności penalizacji w ogólnym rozrachunku odnosiły skutek odwrotny do zamierzonego. Szczególnie dotyczyło to młodzieży uczącej się lub studiującej, w przypadku któ-

28 J. Jakubowska-Hara, Środki oddzialywania wychowawczego, [w:] Reforma prawa wykroczeń, t. 1, red. P. Daniluk, Warszawa 2019, s. 312.

29 Por. M. Budyn-Kulik, [w:] Kodeks wykroczeń. Komentarz, red. M. Mozgawa, Warszawa 2007, s. 131-132; T. Grzegorczyk, op. cit., s. 182; A. Zachuta, Postepowanie w sprawach o wykroczenia (czynności wyjaśniające), MoP 2002, nr 5, s. 212.

30 Tak m.in. A. Marek, Prawo wykroczeń (materialne i procesowe), Warszawa 2012, s. 94; W. Kotowski, Kodeks wykroczeń. Komentarz, Warszawa 2009, s. 178; E. Ryś, Stosowanie środków oddzialywania wychowawczego przez inspektorów pracy, „Annales UMCS” 59, 2012, nr 1, s. 69; B. Kurzępa, Kodeks wykroczeń. Komentarz, Warszawa 2008, s. 166. 
rej nierozważne korzystanie z kar dyscyplinarnych pozostających w dyspozycji jednostek dydaktycznych mogło być niekiedy wręcz kryminogenne ${ }^{31}$. Ponieważ wskazane obawy nie straciły zbyt wiele na swej aktualności, należy zgodzić się, że najlepiej byłoby, gdyby funkcjonariusze instytucji odpowiedzialnych za zapobieganie i ściganie wykroczeń sami stosowali środki oddziaływania wychowawczego bez angażowania $w$ to innych podmiotó $w^{32}$, pamiętając zarazem, aby ich celowość nie wymykała się wskazaniom ustawy, a dolegliwość nie przekraczała progu ustalonego dla środków już w niej wymienionych ${ }^{33}$. Taka propozycja odniosłaby i ten pozytywny skutek, że pozwoliłaby przynajmniej w jakimś stopniu uściślić przedmiotowy zakres omawianej regulacji, zwłaszcza że doktryna akceptuje dziś niemal powszechnie praktykę przekazywania sprawy innemu podmiotowi w celu zastosowania tego rodzaju środków oddziaływania wychowawczego, które dla organów uprawnionych są ogólnie niedostępne (na przykład przekazanie sprawy kierownikowi zakładu pracy w celu wymierzenia kary porządkowej przewidzianej w przepisach k.p., jeżeli wykroczenie ma charakter naruszenia pracowniczego) ${ }^{34}$, czym niewątpliwie rozmywa granice ustawowej charakterystyki wspomnianej kategorii środków reakcji. A przez to uniemożliwia też spełnienie przez art. 41 k.w. wymogu zupełności w zakresie podstawowych pojęć związanych z materią, którą reguluje.

Podobne niedopasowanie uwidacznia się przy okazji analizy podmiotów uprawnionych do stosowania środków oddziaływania wychowawczego. Przepis art. 41 k.w. przemilcza bowiem także tę kwestię. Tymczasem nieoznaczenie uprawnionych organów pośrednio przekłada się na niemożność bliższego określenia rodzajów środków (poza trzema wymienionymi w tym przepisie) zaliczanych do kategorii środków oddziaływania wychowawczego. Z kolei niedopowiedzenie w zakresie obu tych elementów stwarza realne niebezpieczeństwo pociągnięcia do odpowiedzialności dwa razy za ten sam czyn ${ }^{35}$. Sprawę tę komplikuje nadto niejednolite w tej mierze stanowisko doktryny prawa karnego. Zdaniem pewnej części autorów

31 Zob. J. Szumski, Środki alternatywne..., s. 80.

32 R. Krajewski, op. cit., s. 18.

33 Warto dodać, że projekt kodeksu wykroczeń z 2002 roku, rezygnując z przymiotnika „wychowawcze", w ramach tak zwanych środków oddziaływania wymieniał, oprócz trzech znanych już z art. 41 k.w. środków, także ,środek przewidziany w przepisach o odpowiedzialności dyscyplinarnej lub porządkowej".

${ }^{34}$ I. Nowicka, R. Kupiński, Stosowanie środków oddziaływania wychowawczego w sprawach o wykroczenia, Prok. i Pr. 2004, nr 7-8, s. 147. Zob. też W. Radecki, op. cit., s. 414; T. Grzegorczyk, op. cit., s. 182. Odmiennie J. Lewiński, Środki oddziaływania wychowawczego. Przedawnienie orzekania i wykonania kary oraz zatarcie skazania, „Gazeta Policyjna” 1999, nr 19, s. 4; M. Grudecki, Kara nagany i środki oddziaływania społecznego oraz środki oddziaływania wychowawczego w prawie wykroczeń, Prok. i Pr. 2018, nr 7-8, s. 183-184. Odmiennie O. Włodkowski, Środki oddziaływania wychowawczego w prawie wykroczeń (uwagi de lege lata i postulaty de lege ferenda), MoP 2019, nr 14, Legalis (dostęp: 20.02.2020).

35 T. Bojarski, [w:] Kodeks wykroczeń. Komentarz, red. T. Bojarski, Warszawa 2015, s. 126. 
kompetencje w zakresie stosowania środków oddziaływania wychowawczego mają nie tylko sądy, lecz także organy mogące występować w charakterze oskarżyciela publicznego w sprawach o wykroczenia ${ }^{36}$. Według innych art. $41 \mathrm{k} . \mathrm{w}$. skierowany jest wprost do organów upoważnionych do składania wniosków o ukaranie, przede wszystkim do oskarżycieli publicznych, w tym między innymi policji tudzież innych instytucji państwowych oraz samorządowych ${ }^{37}$. Są wreszcie autorzy uznający, że uprawnienie do stosowania środków oddziaływania wychowawczego na pewno ma sąd, natomiast już niekoniecznie podmioty odgrywające rolę oskarżyciela publicznego ${ }^{38}$. Tymczasem uwarunkowania historyczne pozwalają przyjąć, że jest akurat zupełnie odwrotnie. Całe nieporozumienie bierze się z niedostrzeżenia faktu, że oprócz środków oddziaływania wychowawczego w prawie wykroczeń funkcjonuje też z powodzeniem odrębna instytucja — środków oddziaływania społecznego. I o ile te pierwsze może stosować wyłącznie organ uprawniony do składania wniosków o ukaranie, o tyle te drugie sąd, tylko gdy odstępuje od wymierzenia kary ${ }^{39}$. $\mathrm{Z}$ tego dalej wynika, że środki oddziaływania wychowawczego mogą być stosowane na przedsądowym etapie postępowania w sprawach o wykroczenia, $w$ tym w ramach postępowania mandatowego, nie może natomiast korzystać z ich dobrodziejstwa sąd, gdyż uznając sprawcę winnym popełnienia zarzucanego mu czynu, musi wydać wyrok skazujący, rozstrzygając co do kary, o czym stanowi art. 82 § 2 k.p.w., a w razie odstąpienia od wymierzenia kary może zastosować wyłącznie środek oddziaływania społecznego na podstawie art. 39 k.w. ${ }^{40}$

Całkowicie zaniedbana jest także sprawa przesłanek zastosowania środków oddziaływania wychowawczego. Przepis art. 41 k.w. w swej obecnej redakcji poprzestaje bowiem na dość mglistym określeniu, że mają być one „wystarczające”. Rezygnując $\mathrm{w}$ tym względzie $\mathrm{z}$ jakichkolwiek rekomendacji, pozostawia $\mathrm{w}$ istocie organom je stosującym nadmierną swobodę, graniczącą wręcz z dowolnością, która może prowadzić do naruszenia zasady równości wobec prawa ${ }^{41}$. Nie da się przecież wykluczyć, że w konkretnym wypadku o takim, a nie innym potraktowaniu sprawcy decydować będą rozmaite, często zupełnie nieuchwytne, okoliczności (na przykład „układy” personalne czy względy koniunkturalne). Taka dwuznaczność z całą pewnością nie powinna mieć miejsca przy wydawaniu rozstrzygnięć prawnych. Warto przypomnieć, że w poprzedniej regulacji występowała przesłanka uznania tychże środków ,za wystarczające do wdrożenia sprawcy do poszanowania prawa i zasad współżycia społecznego", która — choć miała charakter ocenny — pozwalała przynajmniej na interpretację, że decyzja o ich zastosowaniu

36 B. Kurzępa, op. cit., s. 167.

37 W. Radecki, [w:] M. Bojarski, W. Radecki, Kodeks wykroczeń. Komentarz, Warszawa 2011, s. 329.

38 T. Bojarski, [w:] Kodeks..., s. 126.

39 I. Nowicka, R. Kupiński, op. cit., s. 153-154.

40 R. Krajewski, op. cit., s. 16.

41 J. Szumski, Środki penalne..., s. 198. 
powinna opierać się na pozytywnej prognozie dotyczącej przyszłego zachowania sprawcy. Mimo pewnej niedoskonałości niewątpliwie była ogólną wskazówką dla organów ścigania i orzekania ${ }^{42}$. Tymczasem obecnie ze względu na deficyt ustawowej regulacji przyjmuje się, że art. 41 k.w. dotyczy właściwie każdego wykroczenia, a organ uprawniony do złożenia wniosku o ukaranie czy nałożenia grzywny w drodze mandatu karnego może zawsze, bez zastanawiania się nad wystarczalnością środków oddziaływania wychowawczego i bez kontroli prokuratorskiej, poprzestać na ich zastosowaniu ${ }^{43}$. Wprawdzie formalnie nie ma przeszkód do takiej interpretacji, jednak nie wydaje się, aby intencją ustawodawcy była tak daleko posunięta arbitralność w ocenie organów ścigania. Właściwy sens omawianego przepisu należy bowiem wywodzić z podstawowych zasad obowiązujących na gruncie prawa wykroczeń ${ }^{44}$. Dlatego też zasadniczym kryterium rezygnacji z kary powinien być niewielki czy wręcz subminimalny stopień społecznej szkodliwości czynu, przy którym można przypuszczać, że środek natury wychowawczej będzie wystarczający do wdrożenia sprawcy wykroczenia do poszanowania prawa ${ }^{45}$. W stosowaniu tej pozapenalnej formy reakcji chodzi wszak o umocnienie nawyków i postaw rozważnego postępowania, gdyż tylko wewnętrzne nastawienie sprawcy, nacechowane poczuciem odpowiedzialności, jest gwarancją właściwego zachowania w przyszłości. Dlatego tak ważna jest sprawa racjonalizmu w ocenie czynu tudzież jego sprawcy ${ }^{46}$.

Do rozważenia pozostaje wreszcie problem, który wiąże się z możliwością kumulacji dolegliwości będących reakcją na wykroczenie ${ }^{47}$. W świetle istniejących unormowań nie jest do końca jasna kwestia zakazu wystąpienia do sądu z wnioskiem o ukaranie przez organ, który wcześniej zastosował wobec sprawcy środek oddziaływania wychowawczego. Nowelizacja z 1998 roku (skreślenie art. 40 k.w.) pozbawiła organ orzekający, po wniesieniu sprawy, możliwości jej skierowania do innego podmiotu w celu zastosowania środków oddziaływania wychowawczego będących w gestii tego podmiotu, wobec czego obecnie sąd ma jedynie możliwość odmowy wszczęcia lub umorzenia postępowania, gdy uzna zastosowany uprzednio środek oddziaływania wychowawczego za wystarczającą reakcję na wykroczenie (art. $61 \S 1$ pkt 2 k.p.w.). Wprawdzie w literaturze twierdzi się, nie bez racji zresztą, że zastosowanie tego rodzaju środka powinno wiązać się z odstąpieniem od kierowania wniosku o ukaranie do sądu ${ }^{48}$, jednak z treści samej

42 J. Jakubowska-Hara, Środki oddziaływania..., s. 314.

43 W. Radecki, [w:] M. Bojarski, W. Radecki, Kodeks..., 2016, s. 410.

44 J. Jakubowska-Hara, Środki oddziaływania..., s. 314.

45 T. Grzegorczyk, op. cit., s. 181; M. Budyn-Kulik, op. cit., s. 131; M. Bojarski, Z. Świda, Podstawy materialnego i procesowego prawa o wykroczeniach, Wrocław 2002, s. 102.

46 J. Jakubowska-Hara, Środki oddziaływania..., s. 314.

47 Szerzej na ten temat R. Krajewski, op. cit., s. 17-18.

48 Zdaniem T. Grzegorczyka postępowanie sądowe jest wprawdzie dopuszczalne, tyle że z określonych przyczyn nie jest celowe jego prowadzenie (idem, [w:] Kodeks postępowania w sprawach o wykroczenia. Komentarz, red. T. Grzegorczyk, Warszawa 2012, s. 259; idem, Nowela do pra- 
ustawy nic takiego nie wynika. Nie formułuje ona bowiem wprost nakazu takiego postępowania. A jeśli do tego dodamy jeszcze przepis art. 5 k.p.w., w myśl którego uprzednie zastosowanie środków oddziaływania wychowawczego nie jest bezwzględną przesłanką wyłączającą wszczęcie oraz prowadzenie postępowania, tym pewniejsza staje się konkluzja, że formalnie istnieje możliwość wystąpienia $\mathrm{z}$ wnioskiem o ukaranie ${ }^{49}$. I tym pewniejsze jest też prawdopodobieństwo pociągnięcia sprawcy do odpowiedzialności dwa razy za ten sam czyn. Przy takim zaś ryzyku łatwo o nadmiar dolegliwości w sprawach o czyny drobne, jakimi z natury są wykroczenia ${ }^{50}$, chociaż sam przepis art. 41 k.w. wyraźnie mówi o „poprzestaniu na zastosowaniu tych środków", które to poprzestanie zgodnie z intuicją językową należałoby rozumieć jako coś o skutkach trwałych, a więc nieodwracalnych ${ }^{51}$. Wydaje się, że przezwyciężenie tej niekonsekwencji przynieść może tylko odpowiednia modyfikacja art. 5 k.p.w., polegająca na uczynieniu z przedmiotowej okoliczności bezwzględnej przeszkody procesowej dla wszczęcia oraz prowadzenia postępowania sądowego ${ }^{52}$. Poza wyeliminowaniem dotychczasowych nieporozumień wspomniane rozstrzygnięcie odniosłoby i ten pozytywny skutek, że pozwoliłoby wreszcie uwypuklić właściwy, acz alternatywny względem wniosku o ukaranie charakter środków oddziaływania wychowawczego ${ }^{53}$. Obowiązująca w tym zakresie konstrukcja niepotrzebnie bowiem komplikuje całą tę sprawę.

Mimo że art. 41 k.w. nie spełnia wymogu określoności reakcji prawnej na czyn zabroniony, utrzymanie tej swoistej dla systemu prawa wykroczeń regulacji również obecnie jawi się jako oczywista konieczność. A wyeliminowanie jej i wprowadzenie zamiast tego bezwzględnego obowiązku ścigania i karania (na przykład w postaci nałożenia grzywny mandatem karnym) pozostaje tak jak niegdyś nie do zaakceptowania. W konsekwencji wszelkie propozycje usunięcia z obszaru wykroczeń instytucji środków oddziaływania wychowawczego trzeba stanowczo odrzucić 54 . Najprawdopodobniej wynikają one z niedokładnej znajomości czy też rozpoznania natury prawa wykroczeń. Potrzeba istnienia w tej dziedzinie prawa tego rodzaju alternatywnej płaszczyzny oddziaływania (w drobniejszych naruszeniach zupełnie

wa wykroczeń. Komentarz, Kraków 1999, s. 34). Również zdaniem R. Krajewskiego i B. Kurzępy zastosowanie omawianego środka stanowi wyraz rezygnacji z ukarania sprawcy wykroczenia i nie powinno skutkować wystąpieniem z wnioskiem o ukaranie (B. Kurzępa, op. cit., s. 167; R. Krajewski, op. cit., s. 17).

49 Taką interpretację akceptują I. Nowicka i R. Kupiński, op. cit., s. 148.

50 J. Szumski, O niektórych środkach karnych w projekcie reformy prawa karnego, PiP 1990, nr 11.

${ }^{51}$ R. Krajewski, op. cit., s. 17-18.

52 Ibidem, s. 18.

53 T. Bojarski, Kilka uwag ogólnych o środkach reakcji na czyny zabronione stanowiace przestępstwa $i$ wykroczenia, [w:] Nauki penalne wobec problemów współczesnej przestępczości. Księga jubileuszowa Profesora Andrzeja Gaberle, red. K. Krajewski, Warszawa 2007, s. 23.

${ }^{54}$ Zob. petycja, http://www.sejm.gov.pl/Sejm8.nsf/agent.xsp?symbol=PETYCJA\&NrPetycji=BKSP-145-441/18 (dostęp: 20.02.2020). 
wystarczającej) nie zwalnia jednak ustawodawcy z obowiązku dbania o właściwe jej unormowanie, szczególnie że aktualnie obowiązująca regulacja środków oddziaływania wychowawczego pod wieloma względami wyraźnie nie domaga. Przepis art. 41 k.w., będący w rzeczywistości jedyną materialną podstawą stosowania tych środków, jest przepisem wysoce niedookreślonym, wywołującym rozliczne wątpliwości interpretacyjne w wielu podstawowych kwestiach. Wszystkie one bez wątpienia utrudniają prawidłowe korzystanie z tej instytucji, a na pewno poważnie osłabiają jej funkcję alternatywną wobec kary za wykroczenia. Jeśli zatem chcemy, aby była ona nadal realną przeciwwagą dla penalnych form oddziaływania, to stanowczo należy poddać ją dobrze przemyślanej korekcie.

\title{
SOME REMARKS ON THE CURRENT MODEL OF EDUCATIONAL IMPACT MEASURES
}

\begin{abstract}
Summary
In this study the author discusses an institution which enables you to settle a case for an offence in a different mode of proceedings and applying different measures than provided in criminal regulations. Emphasising the indisputable advantages of this resolution indicates that the design/structure of educational impact measures are not without flaws and faults. Her attention is focused especially on the aspects of its functioning, which require urgent intervention by the legislator. The author concludes that leaving the normalising in question without any changes, exposes it to a conflict/contradiction with one of the fundamental rules of criminal law, namely the nullapoena sine lege rule.
\end{abstract}

Keywords: offence, educational impact measures, alternative punishment

\section{BIBLIOGRAFIA}

Błotnicka-Solak M., Tropami spraw przekazanych $i$ wystąień sygnalizacyjnych. Z badań nad skutecznościq stosowania art. 41 k.w. $i$ art. 5 k.p.w. w praktyce kolegiów woj. tarnowskiego, ZW 1978, z. 1.

Bojarski M., Świda Z., Podstawy materialnego i procesowego prawa o wykroczeniach, Wrocław 2002.

Bojarski M., Radecki W., Kodeks wykroczeń. Komentarz, Warszawa 2011.

Bojarski M., Radecki W., Kodeks wykroczeń. Komentarz, Warszawa 2016.

Bojarski T., Kilka uwag ogólnych o środkach reakcji na czyny zabronione stanowiace przestepstwa i wykroczenia, [w:] Nauki penalne wobec problemów wspótczesnej przestępczości. Księga jubileuszowa Profesora Andrzeja Gaberle, red. K. Krajewski, Warszawa 2007.

Bojarski T., Polskie prawo wykroczeń. Zarys wyktadu, Warszawa 2014.

Grudecki M., Kara nagany i środki oddziaływania społecznego oraz środki oddziaływania wychowawczego w prawie wykroczeń, Prok. i Pr. 2018, nr 7-8.

Grzegorczyk T., Nowela do prawa wykroczeń. Komentarz, Kraków 1999.

Gubiński A., Prawo karno-administracyjne, Warszawa 1968. 
Gubiński A., Prawo wykroczeń, Warszawa 1980.

Gubiński A., Prawo wykroczeń, Warszawa 1989.

Gubiński A., Środki oddziaływania wychowawczego na tle zasady celowości w prawie wykroczeń, PiP 1972, nr 10.

Gubiński A., Siewierski M., Ustawa o przekazaniu niektórych drobnych przestępstw jako wykroczeń do orzecznictwa karno-administracyjnego. Komentarz, Warszawa 1967.

Jakubowska-Hara J., Kilka uwag $w$ kwestii alternatywnych form reakcji na wykroczenia (w kontekście reformy prawa wykroczeń), [w:] Na styku prawa karnego i prawa o wykroczeniach. Zagadnienia materialnoprawne oraz procesowe. Ksiegga jubileuszowa dedykowana Profesorowi Markowi Bojarskiemu, red. J. Sawicki, K. Łucarz, Wrocław 2016.

Jakubowska-Hara J., Środki oddziatywania wychowawczego, [w:] Reforma prawa wykroczeń, t. 1, red. P. Daniluk, Warszawa 2019.

Jakubowska-Hara J., Wymiar kary za wykroczenia (rozwój ustawodawstwa do kodyfikacji z 1971 r.), SP $1989, \mathrm{nr} 4$.

Kodeks postępowania w sprawach o wykroczenia. Komentarz, red. T. Grzegorczyk, Warszawa 2012.

Kodeks wykroczeń, red. T. Grzegorczyk, Warszawa 2013.

Kodeks wykroczeń. Komentarz, red. M. Mozgawa, Warszawa 2007.

Kodeks wykroczeń. Komentarz, red. T. Bojarski, Warszawa 2015.

Kotowski W., Kodeks wykroczeń. Komentarz, Warszawa 2009.

Krajewski R., Środki oddzialywania wychowawczego w prawie wykroczeń, Pal. 2013, nr 7-8.

Kurzępa B., Kodeks wykroczeń. Komentarz, Warszawa 2008.

Lewiński J., Środki oddziaływania wychowawczego. Przedawnienie orzekania i wykonania kary oraz zatarcie skazania, „Gazeta Policyjna” 1999, nr 19.

Marek A., Prawo wykroczeń (materialne i procesowe), Warszawa 2012.

Nowicka I., Kupiński R., Stosowanie środków oddziaływania wychowawczego w sprawach o wykroczenia, Prok. i Pr. 2004, nr 7-8.

Ryś E., Stosowanie środków oddziaływania wychowawczego przez inspektorów pracy, „Annales UMCS" 59, 2012, nr 1.

Sikorska T., Przekazano zakładowi pracy... Pierwsze doświadczenia $i$ wnioski - na tle badań przeprowadzonych $w$ Warszawie, ZW 1972, nr 2.

Skupiński J., Kierunki doskonalenia polskiego prawa wykroczeń, SP 1981, nr 4.

Skupiński J., Model polskiego prawa o wykroczeniach, Warszawa 1974.

Skupiński J., Obowiazek składania przez organy państwowe wniosków o ukaranie przez kolegia karnoadministracyjne, [w:] Funkcjonowanie administracji w świetle orzecznictwa, t. 3, Warszawa 1971.

Skupiński J., Przekazanie niektórych drobnych przestępstw do orzecznictwa karno-administracyjnego, PiP 1967, nr 1.

Świtała K., Nowe prawo o wykroczeniach, ZKA 1969, nr 6.

Szumski J., O niektórych środkach karnych w projekcie reformy prawa karnego, PiP 1990, nr 11.

Szumski J., Środki alternatywne wobec kary za wykroczenia (w zwiąku z projektem kodeksu wykroczé́), PiP 1992, nr 12.

Szumski J., Środki penalne w polskim prawie wykroczeń na tle doświadczeń praktyki, Lublin 1995.

Włodkowski O., Środki oddziaływania wychowawczego w prawie wykroczeń (uwagi de lege lata i postulaty de lege ferenda), MoP 2019, nr 14, Legalis.

Zachuta A., Postępowanie w sprawach o wykroczenia (czynności wyjaśniające), MoP 2002, nr 5. 